\title{
A Project Progress Measurement and Management System
}

\author{
Sangyoon Chin ${ }^{1}$, Suwon Yoon ${ }^{1}$, Yea-Sang Kim ${ }^{1}$, Youngsoo Jung ${ }^{2}$, \\ Soon-Chan Park ${ }^{3}$, and Moonhun Chung ${ }^{3}$
}

1) Dept. of Architectural Engineering, Sungkyunkwan Univ., Suwon 400-746, Korea

schin@skku.ac.kr,yoonsuwon@skku.edu,yskim2@yurim.skku.ac.kr

2) College of Architecture, CAUD, Myongji Univ., Yongin 449-728, Korea

yjung97@mju.ac.kr

3) Research Inst. of Construction. Technology, Samsung Corp., Seongnam 463-721, Korea richpark@samsung.com,moonhun@samsung.com

\begin{abstract}
A progress management in construction projects plays an important role in providing as-built information for project planning, control, cost engineering, and many others. However, progress information has not been collected through objective methods or criteria but mainly based on an individual's own experience or subjective judgment, which results in the limits of consistency, objectiveness, and accuracy in the progress management. This research aims at proposing a progress measurement framework that allows managing and applying various measurement methods dependent on work items to overcome the problems and limits of the current progress management. The framework was developed with a focus on integration of work breakdown structure, cost breakdown structure, and progress measurement methods, and it consists of three main objects: work, activity, and progress measurement unit. Base on the framework, an information system named PROSYS (project PRogress management SYStem) was developed to generate activities and progress measurement units depending on the characteristics of projects and work items, and to keep track of project progress more efficiently and effectively.
\end{abstract}

Keywords: Progress management, Progress measurement, Information system

\section{INTRODUCTION}

Project management information systems are increasingly applied at construction projects for more efficient management by collecting as-built information and supporting decision-making. Among the various types of as-built information, the project progress rate is one of the critical indices that represent the project performance and progress state, and it helps timely and accurate decision-makings by providing basic information that can be applied to project planning and control as well as cost engineering. However, the project progress management has not been quite effective, since it has not been based on objective data or criteria, but based on subjective judgments and different criteria dependent on an individual's experiences or preferences [1].

Regarding research on the progress management, Thomas and Mathews [2] classified the progress management into three categories by the progress measurement method, which are estimated percent complete, physical progress measurement, and earned value. CII [3] and Flemming and Koppleman [4] classified the measurement methods at more detailed level, and suggested the use of a different method depending on the work item or project condition. However, there has been lack of a framework for applying various measurement methods with considering a work item and project characteristics based on objective and consistent criteria. In most construction projects, measurement methods are used inconsistently project by project without objective criteria, which make it more difficult to accumulate and reuse invaluable as-built information.

The objective of this research is to develop a progress measurement framework, which supports to apply various methods with considering a work item and project characteristics based on objective and consistent criteria. To do so, it was analyzed what kind of measurement methods exist, and how they could be applied differently depending on the characteristics of a work item and a project. Based on the methods, a progress measurement framework was developed to provide various measurement methods, depending on work items and project characteristics. Finally, based on the proposed framework, an information system called PROSYS (project PRogress management SYStem) was developed. 


\section{PROGRESS MANAGEMENT IN CONSTRUCTION PROJECTS}

The definition of the progress management, measurement methods, and their targets were studied through literature review. And they are discussed in the following sections.

\subsection{Definition of Progress Management}

Generally, the progress management is defined differently depending on the aspects of cost engineering and scheduling, respectively [5]. However, in overall view, the progress management can be considered as the integration of cost and schedule [1]. Base on this definition, the progress management in this paper is the measurement and analysis of degree of progress based on measurement quantity as well as its budget, which is the same as budgeted cost work performed (BCWP) of Cost/Schedule Control Systems (C/SCS) [6].

\subsection{Progress Measurement Methods and Targets}

Existing research on progress management, listed in Table 1, suggested various measurement methods and targets in progress management. Measurement methods can be categorized into measuring, estimating, and checking, while targets can be classified into work quantity, milestone, process, and time.

Besides Eldin [7] developed a computer application for the measurement of work progress based on weighted milestones and earned value, and Choi [8] insisted that the effectiveness and efficiency of measuring progress can be maximized through specifying major items that can represent the real work progress.

Although the existing research suggested various measurement methods for work progress, the progress management has not been based on objective criteria but based on the manager's judgments and conveniences. In addition, the consistency and accuracy of work progress can be improved through application of various measurement methods and breakdown of measurement targets at more detailed level, however, this would require tremendous time and efforts to build criteria and to collect data in each project. To the contrary, estimating work progress would reduce the accuracy and consistency, although it does not need time and efforts that much. Therefore, there is a tradeoff relationship between accuracy/consistency and efficiency in progress management [1]

Accordingly, it would be very efficient to build a computerized system that allows various choices for progress measurement dependent on the degree of impact of a work for better accuracy and timeliness in progress management. To do so, a framework needs to be developed to suggest and manage criteria, such as measuring methods, targets, and rules, and to apply them flexibly by work items and project characteristics in a consistent and timely manner.

Table 1 Measurement Methods and Targets

\begin{tabular}{|c|c|c|}
\hline Research & Measurement Method & Measurement Target \\
\hline \multirow{3}{*}{$\begin{array}{c}\text { Thomas \& } \\
\text { Mathews } \\
\text { [2] }\end{array}$} & $\begin{array}{l}\text { Estimated percent } \\
\text { complete }\end{array}$ & $\begin{array}{c}\text { Progress state } \\
\text { (Individual evaluation) }\end{array}$ \\
\hline & $\begin{array}{l}\text { Physical progress } \\
\text { measurement }\end{array}$ & Installed quantity \\
\hline & Earned value & $\begin{array}{l}\text { Measurable level of } \\
\text { work progress }\end{array}$ \\
\hline \multirow{6}{*}{ CII [3] } & Unit completed & Installed quantity \\
\hline & Incremental milestone, & Milestone \\
\hline & Start/finish, supervisor & $\begin{array}{l}\text { Start /finish point of } \\
\text { work }\end{array}$ \\
\hline & Opinion & Progress state \\
\hline & Cost ratio & None \\
\hline & $\begin{array}{c}\text { Weighted or equivalent } \\
\text { units }\end{array}$ & $\begin{array}{c}\text { Finish point or progress } \\
\text { state of work }\end{array}$ \\
\hline \multirow{6}{*}{$\begin{array}{c}\text { Fleming } \\
\& \\
\text { Koppleman } \\
{[4]}\end{array}$} & Weighted milestones & $\begin{array}{c}\text { Finish point of } \\
\text { weighted milestone }\end{array}$ \\
\hline & Fixed formula by task & $\begin{array}{c}\text { Finish point of work } \\
(0-100) \text { or } \\
\text { Start / finish point of } \\
\text { work } \\
(50-50)\end{array}$ \\
\hline & $\begin{array}{c}\text { Percent complete \& } \\
\text { milestones gates }\end{array}$ & $\begin{array}{c}\text { Progress state based on } \\
\text { milestone }\end{array}$ \\
\hline & Earned standards & None \\
\hline & $\begin{array}{l}\text { Apportioned } \\
\text { relationships to } \\
\text { discrete work }\end{array}$ & None \\
\hline & Level of effort & Time of work \\
\hline
\end{tabular}

\section{PROGRESS MEASUREMENT METHODS}

Based the measurement methods listed in Table 1, only the methods that have measurement targets were selected and reaggranged by excluding redundancy and ambiguity in its contents. The reaggranged methods were reviewed through the analysis on existing office construction projects and workshops with construction practitioners in Samsung Corporation. Finally, possible methods in each work item were derived for a typical office project.

\subsection{Derivation of Progress Measurement Methods}

The progress measurement methods by work items were derived in the following manner. First, based on the existing research and paradigm at practice, 3 measurement methods and 6 measurement targets were derived. 3 measurement methods are physical measurement, milestone measurement, and estimated percent completed, and 6 measurement targets are quantities of a single major work item, multiple major work items and all work items, milestone, start/finish point, and percent completed. Secondly, 18 types of measurement methods were generated by 
simply combining 3 methods and 6 targets, and they were narrowed down into 6 measurement methods through brainstorming with construction practitioners with considering applicability and redundancy of the candidate methods. The final 6 measurement methods are listed along with examples in Table 2.

\subsection{Criteria for Applying Measurement Methods}

For more accurate progress management, it is necessary to apply various measurement methods with considering the characteristics of a work item and a project, and objective criteria are essential in this process. Therefore, this research adopted three factors affecting progress measurement accuracy proposed by Jung et al. [9] as criteria to choose an appropriate measurement method for a work item. Those factors are budget weight of a work item, typical durations of activities for a work item and the degree of ease in determining accurate progress rate in each activity. Based on these factors, criteria for applying measurement methods are developed on the assumption that the project progress is measured at the activity level every week.

Table 2. Measurement Methods \& Examples

\begin{tabular}{|c|c|c|c|c|c|c|c|c|c|c|}
\hline \multicolumn{4}{|c|}{ Measurement } & \multicolumn{7}{|c|}{ Examples } \\
\hline \multirow{2}{*}{\multicolumn{2}{|c|}{$\begin{array}{l}\text { Measurement } \\
\text { Methods }\end{array}$}} & \multirow[b]{2}{*}{ Criteria } & \multirow[b]{2}{*}{ Target } & \multirow[b]{2}{*}{ Work } & \multicolumn{5}{|c|}{ Budget items } & \multirow[b]{2}{*}{ Checkpoin } \\
\hline & & & & & No. & Description & Standard & Unit & $\begin{array}{l}\text { Budget } \\
\text { rate }(\%)\end{array}$ & \\
\hline \multirow{3}{*}{1} & \multirow{3}{*}{$\begin{array}{l}\text { Measure } \\
\text { installed } \\
\text { quantity of a } \\
\text { single major } \\
\text { item }\end{array}$} & \multirow{3}{*}{$\begin{array}{l}\text { Activities of this work } \\
\text { item take more than a } \\
\text { week, and budget rate } \\
\text { is relatively high. } \\
\text { A single major budget } \\
\text { item can represent the } \\
\text { work progress. }\end{array}$} & \multirow{3}{*}{$\begin{array}{l}\text { Single } \\
\text { major } \\
\text { budget } \\
\text { item }\end{array}$} & \multirow{3}{*}{ Form } & 1 & Wood form & 3 Times & $\mathrm{m}^{2}$ & 4.0555 & \multirow{3}{*}{$\begin{array}{c}\text { Installed } \\
\text { quantity of } \\
\text { No. } 1 \text { item }\end{array}$} \\
\hline & & & & & 2 & Wood form & 4 Times & $\mathrm{m}^{2}$ & 0.1104 & \\
\hline & & & & & 3 & Wood form & $\begin{array}{c}\text { Round } \\
\text { shape }\end{array}$ & $\mathrm{m}^{2}$ & 0.0424 & \\
\hline \multirow{5}{*}{2} & \multirow{5}{*}{$\begin{array}{l}\text { Measure } \\
\text { installed } \\
\text { quantities of } \\
\text { multiple } \\
\text { major items }\end{array}$} & \multirow{5}{*}{$\begin{array}{l}\text { Activities of this work } \\
\text { item take more than a } \\
\text { week, and budget rate } \\
\text { is relatively high. } \\
\text { Multiple major budget } \\
\text { items can represent the } \\
\text { work progress. }\end{array}$} & \multirow{5}{*}{$\begin{array}{l}\text { Multiple } \\
\text { major } \\
\text { budget } \\
\text { items }\end{array}$} & \multirow{5}{*}{$\begin{array}{c}\text { Interior } \\
\text { decoration } \\
\text { tile }\end{array}$} & 1 & $\begin{array}{l}\text { Ceramic tile } \\
\text { for wall }\end{array}$ & $\begin{array}{c}200 \mathrm{~mm} \\
* 200 \mathrm{~mm}\end{array}$ & $\mathrm{~m}^{2}$ & 0.0241 & \multirow{5}{*}{$\begin{array}{c}\text { Installed } \\
\text { quantity of } \\
\text { No. } 5 \& 6 \\
\text { items }\end{array}$} \\
\hline & & & & & $\ldots$ & $\ldots$ & $\ldots$ & $\ldots$ & $\ldots$ & \\
\hline & & & & & 5 & Tile for wall & $\begin{array}{c}150 \mathrm{~mm} \\
* 150 \mathrm{~mm} \\
\end{array}$ & $\mathrm{~m}^{2}$ & 0.1010 & \\
\hline & & & & & 6 & Tile for floor & $\begin{array}{c}150 \mathrm{~mm} \\
* 150 \mathrm{~mm} \\
\end{array}$ & $\mathrm{~m}^{2}$ & 0.0554 & \\
\hline & & & & & $\ldots$ & $\ldots$ & $\ldots$ & $\ldots$ & $\ldots$ & \\
\hline \multirow{5}{*}{3} & \multirow{5}{*}{$\begin{array}{l}\text { Measure } \\
\text { installed } \\
\text { quantities of } \\
\text { all items }\end{array}$} & \multirow{5}{*}{$\begin{array}{l}\text { Activities of this work } \\
\text { item require intensive } \\
\text { monitoring or large } \\
\text { influence over a } \\
\text { project. } \\
\text { A few budget items are } \\
\text { assigned. }\end{array}$} & \multirow{5}{*}{$\begin{array}{l}\text { All budget } \\
\text { items }\end{array}$} & \multirow{5}{*}{$\begin{array}{c}\text { Gutter \& } \\
\text { downspouts }\end{array}$} & 1 & $\begin{array}{c}\text { Steel } \\
\text { downspouts }\end{array}$ & D100 & $\mathrm{m}$ & 0.0077 & \multirow{5}{*}{$\begin{array}{c}\text { Installed } \\
\text { quantity of } \\
\text { all items }\end{array}$} \\
\hline & & & & & 2 & $\begin{array}{c}\text { Steel } \\
\text { downspouts }\end{array}$ & D150 & $\mathrm{m}$ & 0.0002 & \\
\hline & & & & & 3 & Floor drain & $\mathrm{D} 100$ & EA & 0.0027 & \\
\hline & & & & & 4 & Floor drain & $\begin{array}{c}\text { D150, } \\
\text { ME Room } \\
\end{array}$ & EA & 0.0010 & \\
\hline & & & & & 5 & Roof drain & D150 & EA & 0.0018 & \\
\hline \multirow{4}{*}{4} & \multirow{4}{*}{$\begin{array}{l}\text { Check } \\
\text { start/finish of } \\
\text { works }\end{array}$} & \multirow{4}{*}{$\begin{array}{l}\text { Activities of this work } \\
\text { item take less than a } \\
\text { week, and budget rate } \\
\text { is relatively low. } \\
\text { Activities progress can } \\
\text { be measured by } \\
0 / 100 \% \text { basis, which } \\
\text { means that progress } \\
\text { rate is } 0 \% \text { until the } \\
\text { activity is finished. }\end{array}$} & \multirow{4}{*}{$\begin{array}{l}\text { Finish of } \\
\text { work }\end{array}$} & \multirow{4}{*}{ Handrail } & 1 & $\begin{array}{c}\text { ST'L } \\
\text { Handrail } \\
\end{array}$ & $\begin{array}{c}\mathrm{D}=50 \\
\mathrm{H}=900\end{array}$ & $\mathrm{~m}$ & 0.0021 & Start \\
\hline & & & & & 2 & $\begin{array}{l}\text { Heliport } \\
\text { Handrail } \\
\end{array}$ & \begin{tabular}{|c|}
$\mathrm{D}=50.8 * 4$ \\
$\mathrm{H}=1000$ \\
\end{tabular} & $\mathrm{~m}$ & 0.0401 & {$[0 \%]$} \\
\hline & & & & & 3 & $\begin{array}{c}\text { Cooling- } \\
\text { Tower } \\
\text { Handrail } \\
\end{array}$ & $\begin{array}{c}D=100 * 3 \\
H=900\end{array}$ & $\mathrm{~m}$ & 0.0270 & Finish \\
\hline & & & & & 4 & $\begin{array}{l}\text { Rooftop } \\
\text { Handrail }\end{array}$ & $\begin{array}{l}D=50.8 \\
H=800\end{array}$ & $\mathrm{~m}$ & 0.0784 & [100\%] \\
\hline & & Activities of this work & & & 1 & FSD01 & $\begin{array}{l}750^{*} \\
2100 \\
\end{array}$ & EA & 0.0052 & $\begin{array}{l}\text { Finish } \\
\text { frame }\end{array}$ \\
\hline & & and milestones can be & & Aluminum & $\cdots$ & $\cdots$ & $\ldots$ & $\cdots$ & $\cdots$ & $\begin{array}{c}\text { installation } \\
{[30 \%]}\end{array}$ \\
\hline 5 & $\begin{array}{l}\text { Check } \\
\text { milestones }\end{array}$ & $\begin{array}{l}\text { assigned in each } \\
\text { activity. And different }\end{array}$ & Milestones & $\begin{array}{c}\text { door/ } \\
\text { window } \\
\text { installation }\end{array}$ & 4 & FSD47 & $\begin{array}{c}1900^{*} \\
2100 \\
\end{array}$ & EA & 0.0011 & Finish \\
\hline & & $\begin{array}{l}\text { weights can be } \\
\text { assigned in each }\end{array}$ & & installation & $\ldots$ & $\ldots$ & $\ldots$ & $\ldots$ & $\ldots$ & $\begin{array}{c}\text { door } \\
\text { installation }\end{array}$ \\
\hline & & milestone. & & & 8 & SD51 & $\begin{array}{c}1000^{*} \\
2100\end{array}$ & EA & 0.0003 & {$[70 \%]$} \\
\hline 6 & $\begin{array}{l}\text { Estimate } \\
\text { percent } \\
\text { complete }\end{array}$ & $\begin{array}{l}\text { Activities have very } \\
\text { long durations and its } \\
\text { influence is very small. } \\
\text { Activities do not have } \\
\text { clear targets to } \\
\text { measure for work } \\
\text { progress. The progress } \\
\text { can be determined by } \\
\text { time or progress rate(s) } \\
\text { of other works. }\end{array}$ & None & $\begin{array}{l}\text { Usually indi } \\
\text { is not recom }\end{array}$ & $\begin{array}{l}\text { rect c } \\
\text { menc }\end{array}$ & $\begin{array}{l}\text { ost item is incl } \\
\text { ed for measurit }\end{array}$ & $\begin{array}{l}\text { aded in this } \\
\text { g work prog }\end{array}$ & $\begin{array}{l}\text { ategory } \\
\text { ress. }\end{array}$ & However, & this method \\
\hline
\end{tabular}




\section{A PROGRESS MEASUREMENT FRAMEWORK}

This research propose a progress measurement framework (PMF) based on measurement methods and criteria described in the previous section.

PMF has a three-dimensional structure that integrates work breakdown structure (WBS), cost break down structure (CBS), and measurement, and makes three main objects for progress measurement: work, activity, and progress measurement unit (PMU) as shown in Figure 1.

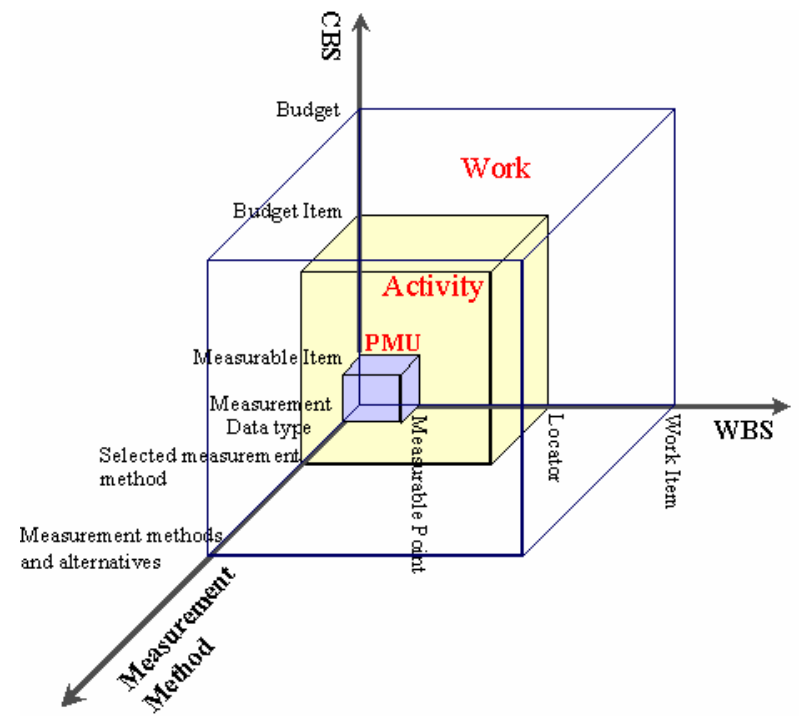

Figure 1. Progress Measurement Framework

WBS defines the structure for activities based on work item, locator, and measurement point. That is, each work item is divided into activities by locations where the work occurs, and activities have one or more measurement points for work progress.

$\mathrm{CBS}$, which is for cost engineering, consists of three factors of budget, budget items, and measurable items. The structure of CBS can be almost identical to WBS at the high level, but CBS usually has the different level of detail from that of WBS. Therefore, in many cases, budget items of a cost account need to be reassigned into activities, and measurable items should be designated among the assigned budget items.

Measurement consists of alternative measurement methods, selected measurement method, and measurement data type. For a given work item, alternative measurement methods are available for progress management; an appropriate measurement method is selected for the work item based on the project characteristics; and progress data is collected in the specified data type to determine the progress at the activity level.

Although WBS is defined as an integrated structure for schedule and cost control systems [10], WBS and CBS are usually managed separately in reality $[11$,
12], which requires reassignments of budget items in CBS into the corresponding activities in WBS. Therefore, PMF defines a work as an integrated object of cost and schedule. Each work has assigned budget items and many alternatives for progress measurement of the work item, while a work progress is determined in each activity by measuring PMUs through the selected measurement method.

Activity is a unit where a progress rate is determined. It is generated through flexible combination of a work item and locators, such as site, building, story, space, and element, depending on the characteristics of a project.

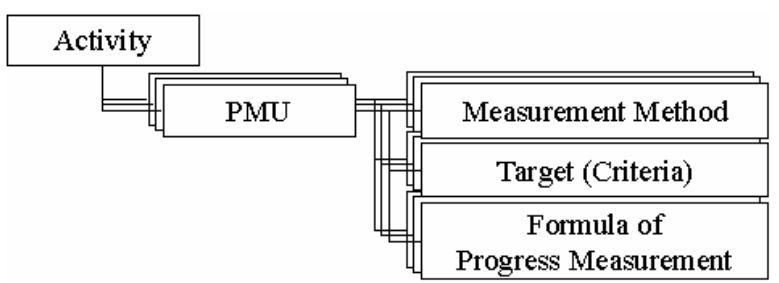

Figure 2. PMU's Structure

PMU, which is a unit to measure a work progress, tells what and how to measure progress for a specific work item, and it consists of measurement method, measurable item(s), and measurement point(s) as shown in Figure 2. An activity has one or more PMUs to measure targets, while a progress rate is determined in each activity through applying PMU values into the formula specified for the selected measurement method. Table 3 shows an example on how work, activity, and PMU are related and a work progress is determined. In addition, the overall project progress rate is determined by:

Proj. Progress $=\frac{\sum \text { (Activity progress } \mathrm{x} \text { budget) }}{\text { Project budget }} \times 100$

\section{SYSTEM IMPLETMENTATION}

An information system named PROSYS (project PRogress management SYStem) has been developed based on the progress measurement framework (PMF) described above. The objective of PROSYS is to support generation of activities and PMUs, integration of cost and activity by reassigning budget items into activities, measurement of work progress by utilizing PDAs, and analysis of work progress, etc. The system architecture and some of main features of PROSYS are presented in the following sections.

\subsection{System Architecture \& Information Flow}

The system architecture of PROSYS is shown in Figure 3. PROSYS has two databases. One is a standard database that contains standard information, such as work items, measurement method and 
Table 3. Examples of Work, Activity, and PMU

\begin{tabular}{|c|c|c|c|c|c|c|c|c|c|c|}
\hline \multirow[b]{2}{*}{ Work } & \multicolumn{2}{|c|}{ Activity } & \multicolumn{4}{|c|}{ PMU } & \multicolumn{2}{|c|}{ Measurement } & \multirow{2}{*}{$\begin{array}{l}\text { Activity } \\
\text { progress } \\
\text { rate }\end{array}$} & \multirow{2}{*}{$\begin{array}{c}\text { Project } \\
\text { progress } \\
\text { rate }\end{array}$} \\
\hline & Name & $\begin{array}{l}\begin{array}{l}\text { Budget } \\
\text { (won) }\end{array} \\
\end{array}$ & $\begin{array}{l}\text { Msrmnt. } \\
\text { Method } \\
\end{array}$ & $\begin{array}{l}\text { Target } \\
\text { (unit) }\end{array}$ & & $\begin{array}{c}\text { Formula for } \\
\text { work progress } \\
\end{array}$ & $\begin{array}{c}\text { Total quantity } \\
\text { of target }\end{array}$ & $\begin{array}{l}\text { Installed } \\
\text { quantity }\end{array}$ & & \\
\hline \multirow{3}{*}{ Formwork } & \multirow[t]{2}{*}{$1 \mathrm{~F}$-formwork } & \multirow[t]{2}{*}{$47,000,000$} & \multirow[t]{2}{*}{ [1] } & \multirow{2}{*}{\multicolumn{2}{|c|}{$\begin{array}{l}\text { Single major budget } \\
\text { item }\left(\mathrm{m}^{2}\right)\end{array}$}} & Installed quantity & \multirow[t]{2}{*}{$2690\left(\mathrm{~m}^{2}\right)$} & \multirow[t]{2}{*}{$1750\left(\mathrm{~m}^{2}\right)$} & \multirow[t]{2}{*}{$65.06(\%)$} & \multirow[t]{2}{*}{$0.08(\%)$} \\
\hline & & & & & & Total quantity & & & & \\
\hline & $2 \mathrm{~F}$-formwork & $47,000,000$ & [1] & \multicolumn{2}{|c|}{$\begin{array}{l}\text { Single major budget } \\
\text { item }\left(\mathrm{m}^{2}\right)\end{array}$} & Installed quantity & $2690\left(\mathrm{~m}^{2}\right)$ & - & $0(\%)$ & $0(\%)$ \\
\hline \multirow{4}{*}{$\begin{array}{c}\text { Door/ } \\
\text { window } \\
\text { installation }\end{array}$} & \multirow{2}{*}{$\begin{array}{c}1 \mathrm{~F}- \\
\text { door/window } \\
\text { installation }\end{array}$} & \multirow[b]{2}{*}{$111,644,500$} & \multirow[b]{2}{*}{ [5] } & $\begin{array}{c}\text { Finish frame } \\
\text { installation }\end{array}$ & $\begin{array}{l}30 \\
(\%)\end{array}$ & \multirow[b]{2}{*}{$\sum$ Weight of milestone } & $\begin{array}{c}\text { Finish frame } \\
\text { installation }\end{array}$ & completed & \multirow[b]{2}{*}{$100(\%)$} & \multirow[b]{2}{*}{$0.3(\%)$} \\
\hline & & & & $\begin{array}{c}\text { Finish } \\
\text { door/window } \\
\text { installation }\end{array}$ & $\begin{array}{l}70 \\
(\%)\end{array}$ & & $\begin{array}{c}\text { Finish } \\
\text { door/window } \\
\text { installation }\end{array}$ & completed & & \\
\hline & \multirow{2}{*}{$\begin{array}{c}2 \mathrm{~F}- \\
\text { door/window } \\
\text { installation }\end{array}$} & \multirow[b]{2}{*}{$111,644,500$} & \multirow[b]{2}{*}{ [5] } & $\begin{array}{c}\text { Finish frame } \\
\text { installation }\end{array}$ & $\begin{array}{l}30 \\
(\%)\end{array}$ & \multirow[b]{2}{*}{$\sum$ Weight of milestone } & $\begin{array}{c}\text { Finish frame } \\
\text { installation }\end{array}$ & completed & \multirow[b]{2}{*}{$30(\%)$} & \multirow[b]{2}{*}{$0.09(\%)$} \\
\hline & & & & $\begin{array}{c}\text { Finish } \\
\text { door/window } \\
\text { installation }\end{array}$ & $\begin{array}{l}70 \\
(\%)\end{array}$ & & $\begin{array}{c}\text { Finish } \\
\text { door/window } \\
\text { installation }\end{array}$ & - & & \\
\hline
\end{tabular}

alternatives and typcial budget items for each work item and it is managed by standard manager. The other database is a project database managed by customization manager, and it manages projectspecific information, such as the project schedule, activities, cost account and budget items, PMUs, etc. The progress measurement manager enables to measure progress based on generated PMUs, and it supports data collection through PDAs for more efficinet progress measurement. Accordingly, the information in PROSYS flows from standard manager to customization manager, and to progress measurement manager.

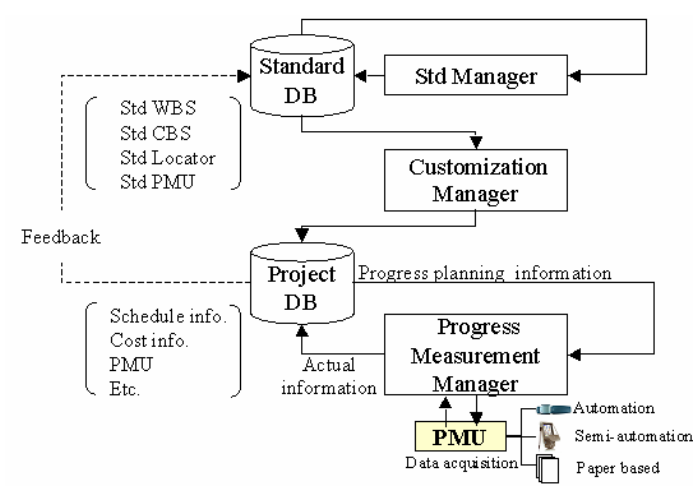

Figure 3. System Architecture

\subsection{PROSYS}

Some of main functions in PROSYS are presented in this section. Figure 4 shows the function to generate activities for a selected work item. A user selects locators, such as floor, space, and element, for the selected work item in the treeview of the left side of the window. And clicking generation button, in turn, generates activities shown at the bottom of the window in Figure 4.

Figure 5 shows the PMU generation. For the selected work item in the left side of the window, a standard measurement method and alternatives are shown, and the default value can be changed to fit to the project. A measurement method is determined at the work item level, since the system assumes the same measurement method is applied through the all activities that belong to the same work item. This is because of the management convinience. If different methods need to be applied, the work item can be divided into as many items as the number of measurement methods required.

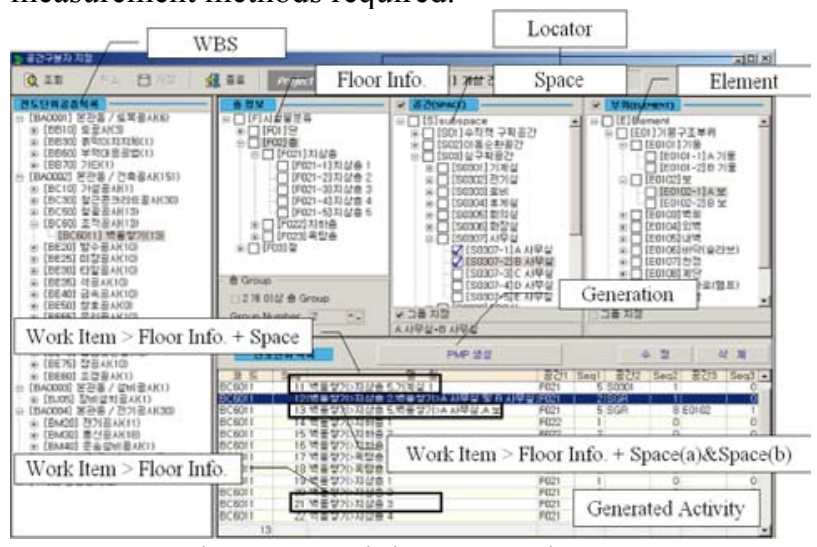

Figure 4. Activity Generation

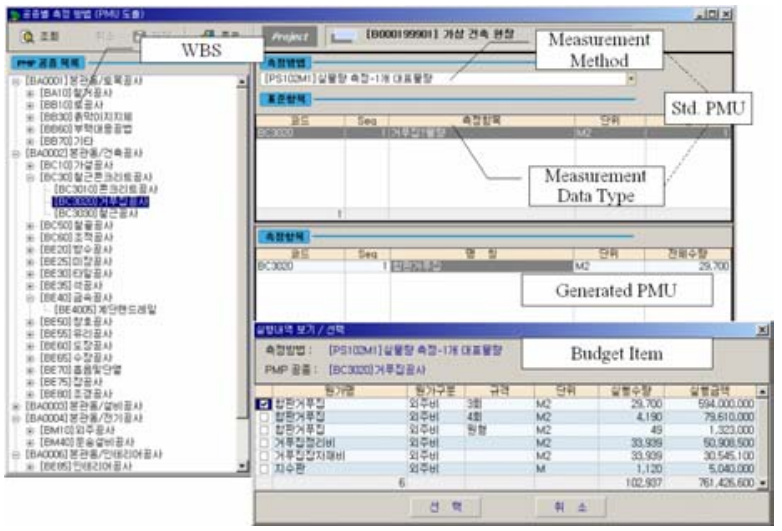

Figure 5. PMU Generation

Figure 6 shows the PDA module of PROSYS. After generating activities and PMUs, a work progress is measured through PMUs by using PDA. The left part of Figure 6 shows the inital page of PDA module, while the right part of Figure 6 shows the measurement window for a specific activity. A user measures progress according to the method specified at PMUs, and then the collected progress data is 
summed and analyzed for project progress analysis as shown in Figure 7.
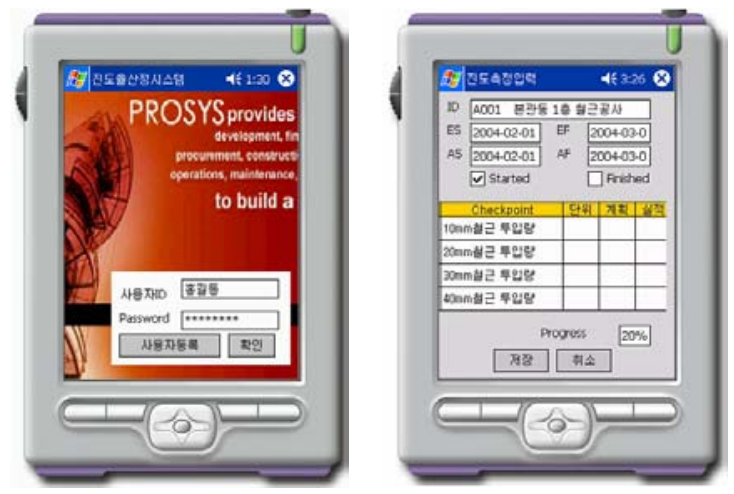

Figure 6. PDA Main \& PMU measurement

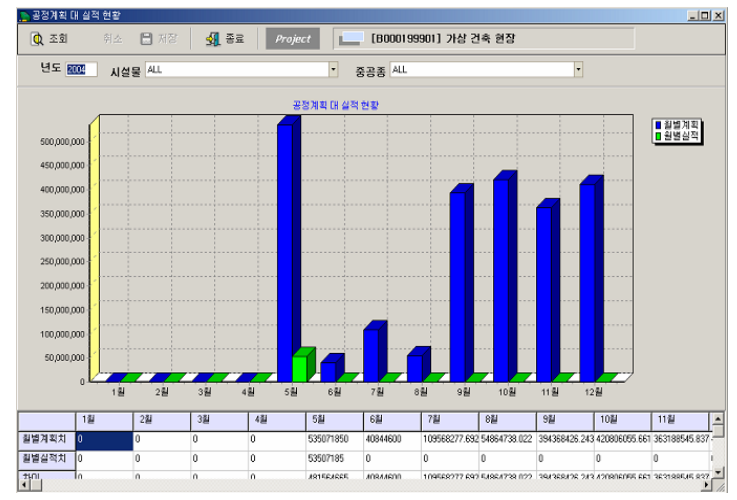

Figure 7. Monthly Progress Rate

\section{CONCLUSIONS}

This research proposed a progress measurement framework and developed an information system for more efficient and effective progress management based on the following outcomes:

1) six measurement methods were derived from the existing research $[2,3,4,7,8]$,

2) the three-dimensional progress measurement framework were proposed on a basis of integrating WBS, CBS, and measurement methods,

3 ) the concept of progress measurement unit was proposed to measure a progress of an activity in a more consistent and objective manner,

4) an information system named PROSYS was developed to support the progress management based on the progress measurement framework.

The proposed progress measurement framework has been partially tested and validated by applying it to construction projects that had already been completed. In the near future, PROSYS will be fully tested for verification and validation of the progress measurement framework through an on-going construction project. Lessons-learned and experience will be shared through further publications.

\section{ACKNOWLEDGMENTS}

This research was performed jointly by Korea Institute of Construction Engineering and Management (KICEM), and Samsung Corporation. Writers in universities have conducted this research project as members of KICEM. This work was also partly supported by Brain Korea 21(D184) at Sungkyunkwan University.

\section{REFERENCES}

[1] Lee, B. Improvements of Determination Methods for Work Progress and Progress Payment in Construction Projects, Construction \& Economy Research Institute of Korea, Korea, 1997

[2] Thomas, H.R. and Mathews, C.T. An analysis of the methods for measuring construction productivity, CII Source Document 13, 1996

[3] CII (Construction Industry Institute) Project Control for Construction, Publication No. 6-5, 1987

[4] Fleming, Q.W. and Koppleman, J.M. Earned value project management, Project Management Institute (PMI), Upper Darby, Pa., USA, 1996

[5] Bae, S. "A Study on Improving Progress Management of Construction Work," Master of Science Thesis, Dept. of Construction and Engineering, Chung-Ang University, Korea, 1989

[6] Farid, F. and Karshenas, S., "C/SCSC Criteria for Measuring Progress under Inflation," Proceeding of the Seminar/Symposium, pp.139-144, Project Management Institute (PMI), Monteral, Canada, September, 1986

[7] Eldin, Neil N. "Measurement of Work Progress: Quantitative Technique," Journal of Construction Engineering and Management, ASCE, 115(3), 1989

[8] Choi, Y. "Construction Progress Measurement System by Tracking the work-done Performance," Korean Journal of Construction Engineering and Management, Vol. 4(3), pp. 137-145, 2003

[9] Jung, Y., Kang, S., Chin, S., Kim, Y., Yoon, S. Cho, C., and Chung, M. "Automated Progress Measurement Framework Using Standard Work Packages," Proceeding of the 4th International Conference on Construction Project Management, Singapore, 2004

[10] Barrie, D.S., and Paulson, B.C. Professional Construction Management Including C.M., DesignConstruct, and General Contracting, McGraw-Hill, Singapore, 1992

[11] Teicholz, P.M. "Current needs for cost control systems," Project controls: Needs and solutions (Proc. Speciality Conf.), ASCE, 1987

[12] Rasdorf, William J. and Abudayyeh, Osama Y. "Cost and Schedule Control Integration: Issues and Needs," Journal of Construction Engineering and Management, ASCE, 117(3), 1991 